Article

\title{
Overlap Between Industrial Niching and Workplace Segregation: Role of Immigration Policy, Culture and Country of Origin
}

\author{
Anastasia Sinitsyna ${ }^{1, *}$, Karin Torpan ${ }^{2,3}$, Raul Eamets ${ }^{4}$ and Tiit Tammaru ${ }^{2}$ \\ ${ }^{1}$ School of Economics and Business Administration, University of Tartu, 50090 Tartu, Estonia; \\ E-Mail: anastasia.sinitsyna@ut.ee \\ ${ }^{2}$ Department of Geography, University of Tartu, 50090 Tartu, Estonia; E-Mails: karin.torpan@ut.ee (K.T.), \\ tiit.tammaru@ut.ee (T.T.) \\ ${ }^{3}$ Department of Geography and Geology, University of Turku, 20500 Turku, Finland \\ ${ }^{4}$ Faculty of Social Sciences, University of Tartu, 50090 Tartu, Estonia; E-Mail: raul.eamets@ut.ee \\ * Corresponding author
}

Submitted: 9 September 2020 | Accepted: 15 December 2020 | Published: 13 May 2021

\begin{abstract}
This article focuses on two dimensions of labour market integration, sorting into different industries (niching) and sorting into workplace establishments (segregation) by share of migrant workers. We seek to understand to what degree these two dimensions of immigrants' lack of labour market integration-niching and segregation-overlap with each other. The study is based on Finnish individual, panel and relational registry data, and we focus on the three largest immigrant groups-Estonians, Russians and Swedes-who have arrived from countries with different wealth levels to the Helsinki metropolitan area. By applying generalised structural equation modelling, we estimate industrial niching and workplace segregation-measured as a degree of overconcentration of immigrants in particular industries and workplace establishments, respectively-jointly. Our main findings show a strong overlap between niching and segregation for all ethnic groups. Segregation and niching levels are the highest among Estonians, but very similar for Russians and Swedes. These findings do not support the cultural similarity argument in immigrant labour market integration. Rather, immigration policy and origin country wealth level may be determinant. Additionally, we found that females are more likely than males to be employed simultaneously in niched industries and segregated workplace establishments, supporting the thesis of gender-based networks.
\end{abstract}

\section{Keywords}

country of origin wealth level; immigration; labour market; niching; segregation

\section{Issue}

This article is part of the issue "Vicious Circle of Segregation: Understanding the Connectedness of Spatial Inequality across Generations and Life Domains" edited by Tiit Tammaru (University of Tartu, Estonia), Siiri Silm (University of Tartu, Estonia), Frank Witlox (Ghent University, Belgium), Maarten van Ham (Delft University of Technology, The Netherlands) and Madli-Johanna Maidla (University of Tartu, Estonia).

(C) 2021 by the authors; licensee Cogitatio (Lisbon, Portugal). This article is licensed under a Creative Commons Attribution 4.0 International License (CC BY).

\section{Introduction}

Immigrant labour market integration is often seen as an important pathway for immigrants' better inclusion in the host society (Tesfai, 2019; Tuccio, 2020). Although many migrants fare well in the labour market, they tend to be overconcentrated in those jobs that are less attrac- tive for natives (Napierała \& Wojtyńska, 2017; Ruiz \& Vargas-Silva, 2018). As a consequence, a 'polarised' or 'dual' labour market may emerge with migrants being overrepresented in jobs with lower pay and lower social security, and natives being overrepresented in jobs with higher pay and higher social security (Christopher \& Leslie, 2015; Halbmeier, 2019; Sassen, 1990). The poor 
labour market performance of immigrants relative to natives has been related to different mechanisms of discrimination and exclusion such as ethnically segregated networks and stereotypical thinking by native employers (Arrow, 1998; Bursell \& Jansson, 2018; Hensvik \& Skans, 2016). Immigrant productive characteristics-e.g., education and formal qualification in the country of origin, as well as previous experiences-are often also of less value in the destination country (Fellini, Guetto, \& Reyneri, 2018).

This article aims to shed new light on immigrant labour market integration by focusing on the overlap between immigrant sorting into certain industries (niching) and workplace establishments (segregation) and how it varies across ethnic groups and different skills levels. In our study, we do not seek to find causal inference as it is assumed in previous research. Instead, we draw our empirical design on the assumption of interdependency, in the further text we refer to it as overlapping, of workplace segregation and industrial niching. By overlapping we assume the degree of interdependency between the levels of workplace segregation and the levels of industrial niching. Previous research shows that both high levels of industrial niching and high levels of workplace segregation may negatively affect immigrant labour market integration associated with workplace segregation (Tomaskovic-Devey, Hällsten, \& Avent-Holt, 2015) and niched employment (Gleave, 2017). Migrants who work both in segregated workplaces and in industrial niches are the most isolated in the host country's labour market and as a consequence, such isolation brings wage penalties (Catanzarite \& Aguilera, 2002). Hence, the negative effect may be even stronger if the work is taking place in both an industrial niche and a migrant-intensive workplace. However, less is known about the extent of the overlap between industrial niching and workplace segregation. This is an important knowledge gap since various dimensions of immigrant integration tend to be related (Tammaru, van Ham, Marcińczak, \& Musterd, 2015).

Building on the seminal work by Wright, Ellis, and Parks (2010), we define industrial niching as an overconcentration of immigrants in certain industries and we define workplace segregation as an overconcentration of immigrants in certain workplace establishments. We seek answers to three research questions: First, to what degree do industrial niching and workplace segregation overlap with each other? Although the study by Wright et al. (2010) theoretically discussed the importance of a joint analysis of niching and segregation, they were not able to strictly measure the overlap between these two dimensions. More specifically, we will advance their research in the following directions: (1) We measure the workplace ethnic composition at the establishment level as is common to matched employeremployee data-based studies (Hellerstein, McInerney, \& Neumark, 2011; Rahnu, Puur, Kleinepier, \& Tammaru, 2019) and (2) adopt a panel research design and we apply generalised structural equation modelling on the data, which allows measuring the overlap between niching and segregation.

Second, are there differences in the overlap between industrial niching and workplace segregation by country of origin? Previous research reveals diverse patterns of labour market integration for different migrant groups (Hedberg \& Tammaru, 2013; Ruiz \& Vargas-Silva, 2018; Wright et al., 2010). Coming from a culturally more distant and economically less affluent country tends to contribute to a bigger disadvantage in the labour market (Tesfai, 2019). Likewise, immigration policies affect migrants from different origin countries in different ways (Söhn, 2013). The country of origin determines labour market position in the host country especially for newlyarrived migrants as the migration policies apply different entry requirements and work permits for different migrant groups.

Third, are there important differences in the overlap between industrial niching and workplace segregation by migrant gender, family status and skills? Previous research shows that niching is more common among lower-skilled migrants and, hence, immigrants tend to niche in manufacturing and the low-paid services sector (Lee, 2019). Niching is more common among men than among women, and men tend to niche into manufacturing and women tend to niche into domestic-workrelated industries (Sánchez-Domínguez \& Fahlén, 2018; Wright et al., 2010). As an innovation to existing studies, we extend our research by incorporating the family context into the analysis. As hiring is strongly based on social networks, marriage to a native partner is an important way to enter into a high segment of the labour market through host-country social networks (Dustmann, Glitz, Schönberg, \& Brücker, 2016; Goel \& Lang, 2019). More specifically, we are interested in whether migrants with a native partner differ from migrants with a migrant partner or without a partner when it comes to niching and segregation on the labour market.

Our study is based on Finnish register data for 2004-2013. The individual level, panel and relational nature of the register data allows us to provide a detailed account on the overlap of industrial niching and workplace segregation and how it varies by origin country, gender and skills. Since several country-specific barriers shape migration, we include countries with low and high migration barriers in the study. As the distance between host and home countries matters, we focus on neighbouring countries of Finland. Sweden and Estonia are culturally close to Finland and, as members of the European Union, enjoy free labour mobility. However, Sweden is more affluent while Estonia is less affluent than Finland. The third country to include in the analysis is Russia. Like Estonia, Russia is less affluent than Finland but unlike Estonia, migrants from Russia face higher obstacles to migration, as do all migrants arriving from outside the European Union. To factor out the differences between host country sub-labour markets (Ellis \& Almgren, 2009; 
Longhi, 2019), our research focuses on migrants living in the Helsinki metropolitan area (HMA).

The structure of the article is as follows. We begin with a literature review, starting with the debates on the 'dual labour market' (Doeringer \& Piore, 1985) and how niching and segregation are related to the restructuring of the labour markets and 'social polarisation' (Sassen, 1990). We extend these debates by discussing how the country of origin context sort migrants in certain industries and workplaces (Åslund \& Engdahl, 2019; Strömgren et al., 2014). Further, we discuss the role of immigrant personal characteristics and social networks (Ellis, Wright, \& Parks, 2004). We proceed with the analysis by presenting descriptive data on immigrant niching and segregation first, followed by regression analysis. The article ends with a discussion of the main findings and the conclusion.

\section{Literature Review}

Although the research traditions on industrial niching and workplace segregation are separated, they offer many similar explanations to immigration labour market integration as related to globalisation, immigration and geographic changes in cities. Globalisation has given rise to large multinational corporations with different functions located in different parts of the world; the labour-intensive footloose jobs in manufacturing moved to low-wage countries while higher-order services, management and coordination functions stayed and expanded in high-wage countries (Sassen, 2011). Such changes have led to the dualisation (Doeringer \& Piore, 1985) or polarisation (Sassen, 1990) of the labour markets.

For immigrants, it is often easier to get access to lower-paid jobs and, as immigration continues, migrants tend to cluster into certain industries and workplaces, leading to the formation of ethnic industrial niches and segregated workplaces (Ansala, Åslund, \& Sarvimäki, 2020; Bygren, 2013; Liu, 2011; Waldinger, 1994). The overlap between industrial niching and workplace segregation of immigrants has several mechanisms that relate to (1) labour demand and personal characteristics of migrants such as age, gender and skills, (2) country of origin of immigrants that shapes the ease of entering the host country and its labour market and (3) social networks that link migrants and employers in countries of origin and destination as both the processes of immigration and hiring tend to hinge on information that flows in social networks.

\subsection{Origin Country Context}

The country of origin matters in industrial niching and workplace segregation of immigrants, e.g., because of cultural and linguistic differences (Penninx, 2005) or procedures of recognition of educational level and previous work experience of the migrants in the host country. Coming from a culturally distant country may pose greater difficulties in skill recognition by the native employers because of the differences in country of origin and the host country's educational systems and labour market structures, sorting migrants to certain jobs and workplaces where skill mismatch is less problematic (Dustmann, Fabbri, \& Preston, 2005; Hayfron, 2001). As a consequence, migrants tend to be over-educated for the jobs they are recruited for (Joona, Gupta, \& Wadensjö, 2014; Visintin, Tijdens, \& van Klaveren, 2015) and, hence, contribute to higher levels of industrial niching and workplace segregation.

Hiring through the ethnic network is very often considered to be a low-cost and risk-free option for the recruitment process (Hoffman, 2017). Companies seek to maximise the benefits of ethnic network hiring: decrease absenteeism at work (Hall, Iceland, \& Yi, 2019; Hanson \& Pratt, 1992), less friction (Liu, 2011) and better communication among ethnic workers (Ely \& Thomas, 2001; Lancee, 2016). To shorten the searching process, many workplaces prefer to hire new workers through recommendations from already-employed workers (Alaverdyan \& Zaharieva, 2019). Often companies use ethnic networks to hire workers from the closest residential areas and consider such living areas as labour pools (Bayer, Ross, \& Topa, 2008; Ellis et al., 2004; Hellerstein et al., 2011; Manning \& Petrongolo, 2017).

The hiring practices of ethnic entrepreneurs may contribute to immigrant niching and segregation as well. Ethnic enterprises often provide specific ethnic goods and services (such as restaurants) and tend to value co-ethnic co-workers not least because of trust but also because of customer demand for authentic goods. Because of those complementary forces, ethnic entrepreneurs tend to be more open to employing migrants compared to employing natives and compared to native entrepreneurs. This contributes to the niching of immigrants into certain industries as well as into certain workplace establishments (Strömgren et al., 2014). Because of the importance of ethnic networks, differences may exist not only between natives and migrants but also between migrants coming from different countries of origin.

Relative income differences between origin and destination countries may also matter concerning the sorting of migrants in the host country labour market. Migrants arriving from a less affluent country are attracted by higher incomes (Halbmeier, 2019). For them, earning higher incomes than in their country of origin may be a sufficient gain from migration. They tend to accept any job offer if relative wage will be higher in comparison with the previous wage in the country of origin. As a consequence, migrants from less affluent countries are employed in unsecure low-skilled jobs with a higher number of working hours and lower wages and cluster more in niched industries and ethnically segregated workplaces. Migrants arriving from more affluent countries often have different aspirations. They may trade lower income in a destination country for more motivating 
career or business opportunities. Multinational companies staffing their branch offices tend to contribute to such moves by circulating managers between countries (Findlay \& Cranston, 2015).

Origin country context also defines the selection process and requirements host countries apply for migrants. Those who emigrate from non-EU countries meet the high level of skills-selection in comparison with the European Union, which benefits from freelabour mobility. Two types of migration policies-sectorand employer-based-are directly related to the sorting into industries and workplace establishments; sectorbased policies contribute to industrial niching and employer-based policies contribute to workplace segregation (Åslund \& Engdahl, 2019). In Finland, our case study country, sector-based and employer-based policies co-exist, producing the overlap between industrial niching and workplace segregation.

\subsection{Personal and Social Characteristics of Migrants}

Although immigration policies set the broad framework for the entry of migrants, the actual migration flows are very diverse. Sorting in the labour market also relates to migrant skills and its interaction with the residential context (Liu \& van Holm, 2019). Most migrants do not have a job waiting for them upon arrival in the host country (Tammaru et al., 2015), and they start looking for a job once settled. Highly-skilled migrants rely more on formal ways in finding a job, while low-skilled migrants tend to rely on ethnic networks and informal ways of finding a job. Newcomers may obtain information about job vacancies from co-ethnics that often relate to industries and workplaces that are already overrepresented by this ethnic group (Telve, 2019). When the host country language skills are poor, which is often the case with newcomers, immigrants are more likely pushed into the niched industry and in a segregated workplace (Liu, 2011).

Ethnic networks help migrants to settle but they may also reduce social inclusion of migrants into the host society and provide less motivation for local language learning (Skaptadóttir, 2019). The job-search process also hinges on the place of residence since workers tend to be disproportionally hired from the nearest residential areas (Ellis et al., 2004; Hellerstein et al., 2011). The ethnic clustering into neighbourhoods such as Chinatowns shapes sorting into industries and workplace establishments.

An important way of entering the social networks in the host country concerns getting married to a native person, which is often considered to be the ultimate form of social integration of migrants (González-Ferrer, Obućina, Cortina, \& Castro-Martín, 2018; Rahnu et al., 2019). Having a native partner improves migrants' language skills, helps them learn the written and unwritten rules of the county and provides accesses to information about the labour market or even job vacancies. There are also important differences in mixed ethnic unions by country of origin; immigrants who share similar cultural values and practices as natives are most likely to intermarry with natives (Klein, 2001; Peach, 2005). The study by Strömgren et al. (2014) further found that migrants married to natives work in less segregated workplaces compared to other migrants.

Industrial niching and workplace segregation are also highly gendered (Ellis et al., 2004; Tammaru, Strömgren, van Ham, \& Danzer, 2016). Given gender stereotypes and gendered social responsibilities, females and males tend to concentrate in different industries and workplaces. Cultural values may shape gender roles at work and at home in a way that has a direct effect both on female labour market participation as well as on their sorting into certain jobs. Because of housekeeping responsibilities and caretaking, females seek employment closer to home. The social networks of migrant women tend to be more neighbourhood-based and their social networks include more co-ethnics. Hence, living in segregated neighbourhoods tends to contribute more to female niching and workplace segregation compared to men (Light \& Nandi, 2007; Tammaru et al., 2016).

\section{Study Design}

\subsection{Research Population}

We derive our empirical evidence from Finland, and our research population includes migrants from its neighbouring countries Estonia, Sweden and Russia arriving between 2004 and 2013. We form the research population based on Finnish individual-level register data. This is a high-quality data set that contains annual observations for every individual registered in Finland. However, information on the education of immigrants is limited, e.g., we are unable to define the particular education level of the person and do not observe the skills level; we use occupational status as a proxy. First, we exclude return migrants or those whose mother tongue is Finnish. Second, our analysis includes only those who live and work in the HMA in order to exclude the regional labour market differences. Third, as one of the focuses of our study is workplace segregation, we also removed self-employed persons and entrepreneurs from the research population. We began by tracking the employment history of the person from their first employment in the HMA. Finally, we included persons aged 25 to 64 for our study. As a result of those restrictions, our final research population includes 29,812 individuals (Table 1 ).

There are some important differences between migrants arriving from different countries of origin. The highest share of those who have a native partner is among Swedes (22\%). The share of migrants employed in upper white-collar occupations is also the highest among Swedes, lowest among Estonians and in-between for migrants who arrived from Russia. Since Russia is not a 
Table 1. Characteristics of the research population by country of origin.

\begin{tabular}{|c|c|c|c|c|}
\hline & & Estonians & Russians & Swedes \\
\hline \multirow[t]{3}{*}{ Gender } & Male & 42.7 & 45.1 & 67.4 \\
\hline & Female & 57.3 & 54.9 & 32.6 \\
\hline & Total (\%) & 100 & 100 & 100 \\
\hline \multirow[t]{5}{*}{ Age group } & $25-34$ & 33.8 & 50.3 & 64.0 \\
\hline & $35-44$ & 28.9 & 27.3 & 26.8 \\
\hline & $45-54$ & 26.4 & 16.1 & 6.9 \\
\hline & $55-64$ & 10.9 & 6.3 & 2.3 \\
\hline & Total (\%) & 100 & 100 & 100 \\
\hline \multirow[t]{7}{*}{ Family status } & Single & 62.1 & 30.9 & 47.8 \\
\hline & Married with native & 2.2 & 7.9 & 22.7 \\
\hline & Married with migrant & 14.9 & 42.6 & 14.0 \\
\hline & Married, partner unknown & 7.1 & 6.8 & 6.5 \\
\hline & Divorced & 13.0 & 10.9 & 8.7 \\
\hline & Widow/er & 0.7 & 0.9 & 0.3 \\
\hline & Total (\%) & 100 & 100 & 100 \\
\hline \multirow[t]{4}{*}{ Years of stay in HMA } & $0-3$ & 71.1 & 52.1 & 65.1 \\
\hline & $3-6$ & 22.5 & 35.1 & 25.3 \\
\hline & $6+$ & 6.4 & 12.8 & 9.6 \\
\hline & Total (\%) & 100 & 100 & 100 \\
\hline \multicolumn{5}{|l|}{ Occupational Group } \\
\hline & Higher white-collar worker & 4.0 & 24.8 & 46.8 \\
\hline & Lower white-collar worker & 16.4 & 27.6 & 30.6 \\
\hline & Manual worker & 79.6 & 47.6 & 22.6 \\
\hline & Total (\%) & 100 & 100 & 100 \\
\hline$N_{\text {observations }}$ & & 21176 & 7357 & 1279 \\
\hline
\end{tabular}

Note: Authors' own calculations based on Finnish registry data set (years 2004-2013) not publicly available.

member of the European Union, Russian migrants fall under the system of work permits-they are allowed to enter to Finland only if they have already concluded an employment contract with the employer from the host country. The migration policy limits the entry of low-skilled non-EU workers and aims to select middle and high-skilled workers for new and innovative industries. Migrants from Estonia do not face such restrictions and hence, lower-income groups seeking a way out of poverty are strongly over-represented among migrants.

As it was revealed in the literature review, migrants are sorted into niche industries due to space and informational limitations (Figure 1). However, they are placed into industries unevenly and some ethnic group members cluster in particular industries. The industrial distribution of Estonians and Russians is similar; the majority of members ( $42 \%$ of Estonians and $37 \%$ of Russians) of both ethnic groups are presented in health care and social work industries. Swedes are also presented in this industry (44\%) but are mainly employed in educational and public activities. The second largest industry for Estonian employees is the construction sector, where $36 \%$ of Estonians are employed. Such uneven industrial distribution strongly depends on the gender structure of the sample as there are historical gender differences and separation of the industries in terms of gender. As it is presented in the Supplementary File (Figure A1), the majority of females (67\% for Estonian females, $47 \%$ for Russian females and $57 \%$ of Swedish females) for 3 ethnic groups are employed in $8^{\text {th }}$ industry which includes health, social work and educational sub-industries. Based on a more detailed classification of industries, Russian and Estonian females are concentrated in social health care, whereas Swedish females are employed mostly in the educational industry. Estonian (68\%) and Russian (33\%) males are employed mostly in the construction industry, which is migrantintensive especially for males, whereas Swedish males (37\%) together with females are presented in education, health and social work activities. Overall, the pattern of industrial ethnic distribution of Estonians and Russians is similar-the majority of both ethnic groups are employed in industries of the secondary sector mostly, while Swedes are presented in industries of the primary sector.

The pattern of workplace segregation levels is also different across ethnic groups as well as industrial ethnic distribution. As presented in Figure 2, on average, Estonians have $48 \%$ of other migrants as co-workers. This finding is explained by the high concentration of 


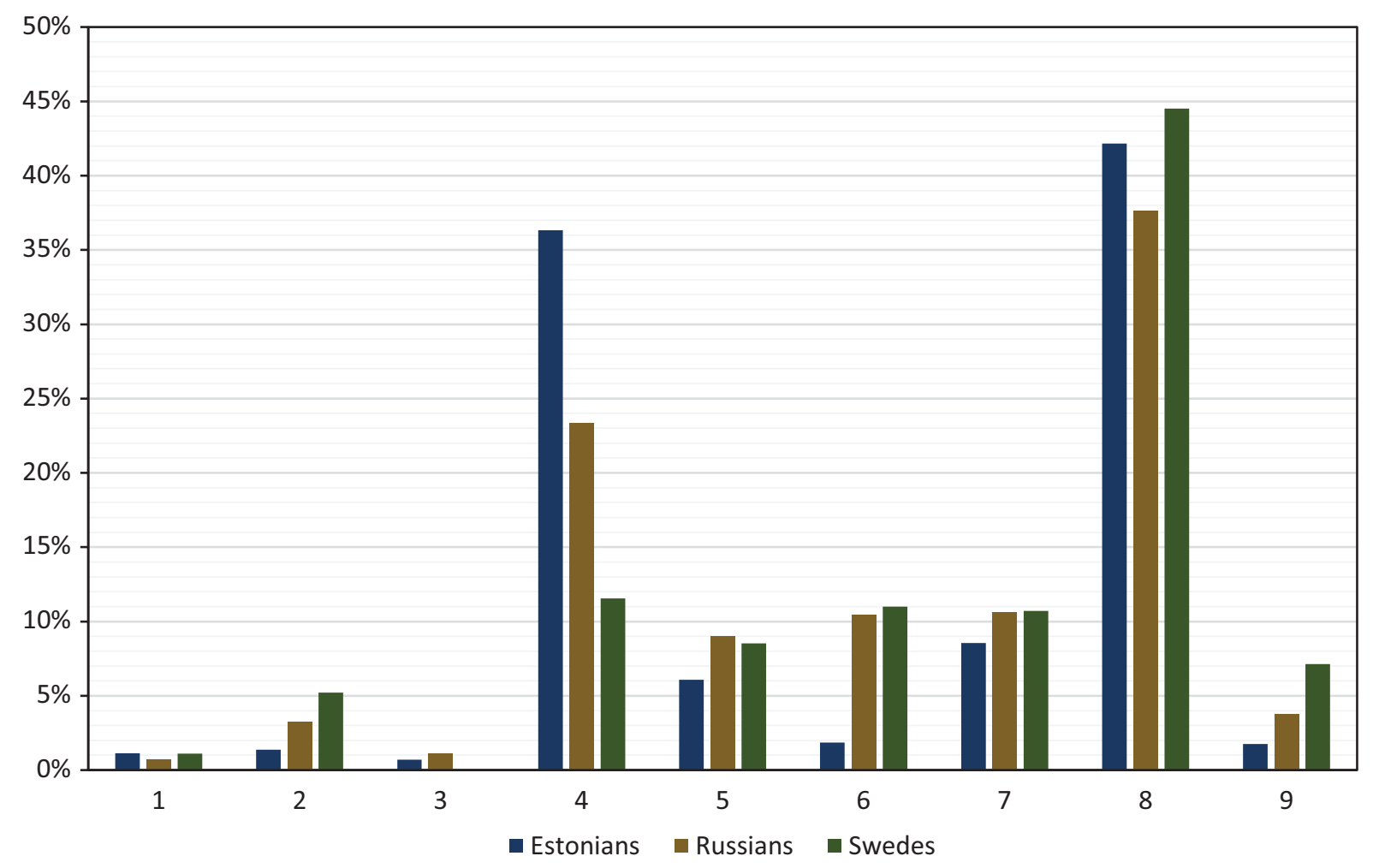

Figure 1. Distribution of ethnic groups (as a share of employed ethnic group members in a particular industry from the total number of employed ethnic group members) across industries in 2013. The aggregated industrial classification based on TOL 2008: (1) Manufacturing; (2) Mining and quarrying; (3) Electricity, gas, steam, air and water supply; (4) Construction, transportation and storage; (5) Accommodation, food and informational service; (6) Financial, insurance and real estate activities; (7) Administrative and support service activities; (8) Public administration, education, health and social work activities; (9) Other service activities (production for own use, repair of computers and household goods, activities in membership organisations). Source: Authors' own calculation based on Finnish registry data set (year 2013) not publicly available.

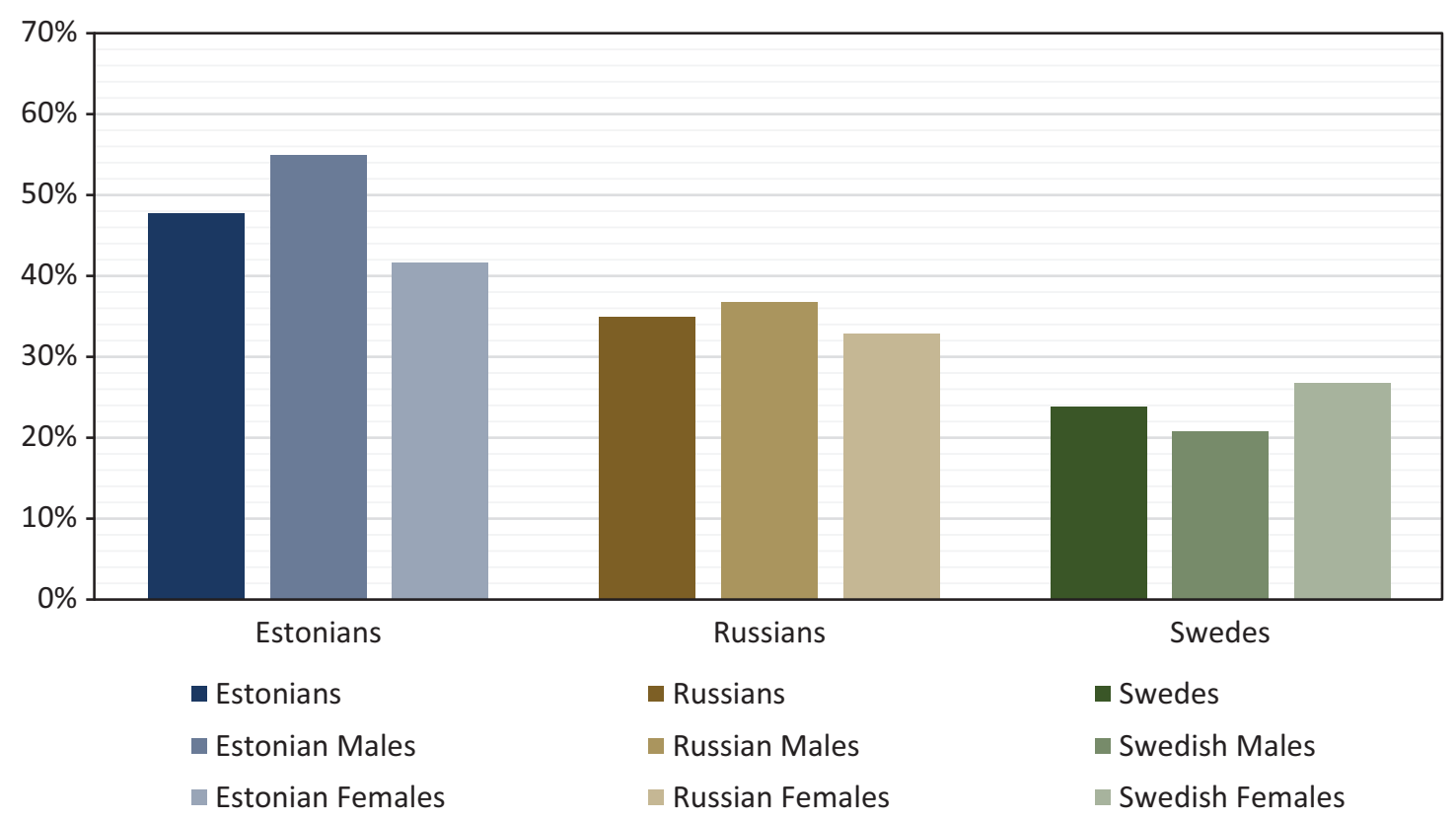

Figure 2. The average share of migrants as co-workers across ethnic groups (total, for males and females) in 2013. Source: Authors' own calculation based on Finnish registry data set (year 2013) not publicly available. 
Estonians in the construction industry, hence, being employed as a construction worker means having more ethnic co-workers in the same establishment. As discussed above, Swedes are employed in the primary sector (in education and public services) and, thus, have significantly lower shares of ethnic co-workers (24\% of ethnic co-workers on average). Immigrants of Russian origin are employed in the migrant-intensive construction industry as well as the health and social care industry, but they have low shares of migrants as co-workers in the workplace. On average, 35\% of the total employees are ethnic co-workers for Russian migrants.

\subsection{Measure of Niching and Segregation}

For a simultaneous estimation of industrial niching and workplace segregation, we need a measure that is applicable for both. Following Wright et al. (2010), we use a workplace location quotient (WLQ) as the measurement of workplace segregation, calculated following Equation 1:

$$
W L Q=\frac{\left(M_{w t} \mid T_{w t}\right)}{\left(M_{t} \mid T_{t}\right)}
$$

Specifications follow:

- $W L Q$ is the workplace location quotient index; $w$ refers to the workplace where migrant lives in year $t$

- $M_{w t}$ is the number of migrant workers in workplace $w$ in year $t$

- $T_{w t}$ is the total number of workers in workplace $w$ in year $t$

- $M_{t}$ is the total number of migrants workers in HMA in year $t$

- $T_{t}$ is the total number of workers in HMA in year $t$

The unit of measurement for workplace segregation is an establishment or a unit of a company/employer that is located at a concrete address. The offices or departments of the company that are located at different addresses are considered as different establishments. We set the minimum number of two employees for the workplace to be included in our analysis. We calculate WLQ based on Equation 1 annually for the period 2004-2013. We apply the threshold proposed by Wright et al. (2010) to define whether an establishment is overrepresented or underrepresented by migrants. If the share of migrants in the particular establishment is $50 \%$ higher than the average share of migrants in all establishments located in the HMA, we identify the establishment as migrant-intensive. Otherwise, if WLQ is less than 1, migrants are underrepresented in this establishment. All workers employed in the same establishment are assigned the same value of the WLQ index.
For industrial niching we use the niche quotient (NQ), which is calculated using Equation 2:

$$
N Q=\frac{\left(M_{j t} \mid O_{j t}\right)}{\left(M_{t} \mid T_{t}\right)}
$$

Specifications follow:

- $N Q$ is the niche quotient index; sub-index $j$ refers to the industry and sub-index $t$ refers to the year

- $M_{j t}$ is the number of migrant workers in industry $j$ in year $t$

- $O_{j t}$ is the total number of workers in industry $j$ in year $t$

- $M_{t}$ is the total number of migrant workers in HMA in year $t$

- $T_{t}$ is the total number of workers in year $t$

We follow Wang and Pandit (2007) and apply the 4-digit level of classification of industry. The calculations for industrial niching are similar to workplace segregation calculations. As with workplace segregation, we use 1.5 threshold level to define sectors where migrants are overrepresented (niched industry) or underrepresented. We assign the same value of industrial niching to migrants working in this industry, focusing on niched or non-niched industries (Wright et al., 2010).

\subsection{Model for Studying the Overlap between Niching and Segregation}

We estimate the system of two generalised structural equation models (GSEM) with two endogenous dummy dependent variables (working in the niched or non-niched industry and working in a segregated or non-segregated workplace) to find answers to our main research questions. The equations are fitted to the panel data with an annual clocking of time, covering the work history of migrants between 2004 and 2013. We model Equations 3 and 4 jointly, and the generalised form of the structural equation model is as follows:

$$
\left\{\begin{aligned}
W S_{i t} & =\beta_{1 t} X_{i t}+u_{1} \\
I N_{i t} & =\beta_{2 t} X_{i t}+u_{2}
\end{aligned}\right.
$$

Specifications follow:

- $W S_{i t}$ is a dependent variable of workplace segregation defining whether the individual $i$ is employed in a segregated workplace or not in year $t$

- $I N_{i t}$ is a dependent variable of industrial niching defining whether the individual $i$ is employed in niched industry or not in year $t$

- $X_{i t}$ is the vector of independent variables with associated coefficients $\beta_{1 t}$ for workplace segregation and $\beta_{2 t}$ for industrial niching respectively 
- $u_{1}$ and $u_{2}$ are bivariate normally distributed errors for workplace segregation and industrial niching equation respectively

Rho is the coefficient of overlap between Equations 3 and 4.

For the Equation 3, the dependent variable measures whether a given migrant works in a workplace where immigrants are either overrepresented (segregated workplace, coded as 1 ) or underrepresented (coded as 0 ). For Equation 4, the dependent variable measures whether a given migrant works in an industry where immigrants are overrepresented (niched industry, coded as 1) or underrepresented (coded as 0).

Our main interest relates to the coefficient of overlap between working in a niche industry and working in a segregated workplace. In GSEM, it is presented as a $R$ ho coefficient that detects an interaction between residual covariance structures of the two equations. The Rho coefficient varies from -1 to 1 . The $R$ ho values between -1 and 0 refer to the negative residual covariance in the two equations, meaning that workplace segregation and industrial niching demonstrate reverse overlapping or interdependency-the increase in one process is associated with the decrease in the other and vice versa. The Rho values between 0 and 1 refer to the positive residual covariance in the two equations, meaning that workplace segregation and industrial niching are positively inter-related to each other. In other words, positive and significant values of the coefficient indicate an overlap between working in a niche sector and working in a segregated workplace.

For both GSEM equations, we include a set of relevant covariates. The first set of variables relate to the socio-demographic characteristics of migrants, including country of origin, age, gender and occupational status (higher white-collar, lower white-collar and manual workers). The following classification of occupations was used. Senior officials and upper management in research, planning, education and training and other activities were identified as the highest white-collar employees. The lower level of white-collar employment is represented by supervisors, clerical and sales workers in independent and routine work as well as in other activities. We classify workers in manufacturing and other production-related workers in agriculture, forestry and fishing, as well as distribution and service workers as manual work. We used occupational classification as a proxy for skills level assuming that the highest level of skills is associated with high white-collar jobs and the lowest for manual workers. We propose that employees of lower white-collar jobs represent the middle-skills level.

The second set of variables relates to migrant integration, including years of stay in the HMA, type of the neighbourhood (whether it is migrant-intensive or not; if the share of migrants in the particular neighbourhood is greater by $50 \%$ than the average share of migrants in the HMA, then this neighbourhood is identified as migrantintensive), family status (single, married or in a registered partnership with native, married or in a registered partnership with migrant, divorced, widow) and host country education (whether the individual has obtained any level of education in Finland or not). To control for reverse causality, we lag the family status and residential neighbourhood variables by 1 year compared to the two dependent variables. Finally, we split the GSEM model and run it separately for each origin country group, gender, family status and occupational groups as a proxy for skills level.

\section{Main Findings}

There are important differences in workplace segregation and industrial niching between migrants from different origin countries. Applying a threshold level of 1.5 implies that all migrant groups are working in niched and segregated workplaces, with levels of segregation being higher than levels of niching. $73 \%$ of migrants from Sweden are employed in segregated establishment and $42 \%$ of them are employed in the niched industry. Among Estonians, the respective figures are $87 \%$ and $68 \%$, and for Russians $77 \%$ and $45 \%$ (Table 2). The share of migrants among co-workers is $48 \%$ for Estonians, $38 \%$ for Russians and $24 \%$ for Swedes. Estonians are highly concentrated in the construction sector, where the share of migrant workers is high. Both Estonian and Russian workers are clustered in health care and social work, where the share of migrant workers is high, too. There is a strong gender dimension in industrial niching for both Estonians and Russians, as men are clustered in the construction sector and women in health care and social work. Gender differences in workplace segregation are not particular for

Table 2. Workplace segregation and industrial niching by country of origin.

\begin{tabular}{llccr}
\hline & & Estonians & Russians & Swedes \\
\hline Workplace type & Segregated & 87.3 & 77.8 & 73.0 \\
& Non-segregated & 12.7 & 22.2 & 27.0 \\
& Total (\%) & 100 & 100 & 100 \\
Industry type & Niched & 68.5 & 45.2 & 42.3 \\
& Non-Niched & 31.5 & 54.8 & 57.7 \\
& Total (\%) & 100 & 100 & 100 \\
\hline
\end{tabular}

Note: own calculations based on Finnish registry data set (years 2004-2013) not publicly available. 
Russians, while Estonian men are found in more segregated workplaces compared to Estonian women. Migrants from Sweden are mainly working in education and public services where the share of migrants is low.

Next, we will explicitly address our three research questions. Our first two research questions asked what the overlap between workplace segregation and industrial niching is, and how it varies over groups originating from Estonia, Russia and Sweden. The GSEM yields a significant and positive Rho coefficient close to 1, referring to a strong overlap between workplace segregation and industrial niching for all migrant origin groups (Table A1 in the Supplementary File). The overlap is the strongest for Estonian migrants (0.83), and lower and very similar for migrants who originate from Russia (0.68) and Sweden (0.69).

The results by socio-demographic variables are as follows. Estonians more likely work in a segregated workplace compared to migrants from Russia and Sweden, while differences in industrial niching are smaller between origin groups. Workplace segregation increases by age while there are no age differences in industrial niching. With the exception of Russian migrants, women are less likely to work in segregated workplaces and niched industries compared to men. Manual workers are working in the most segregated workplaces and the most niched industries. All variables measuring immigrant integration-living longer in Finland, having a Finnish partner, living in a less segregated neighbourhood, and having obtained education in Finland-yield negative associations both with workplace segregation and industrial niching.

Our third research question asked what the overlap between workplace segregation and industrial niching by gender, family status and occupation is as a proxy for skills level. We find that the overlap between industrial niching and workplace segregation is stronger for women than for men (Table 3). Migrants living with a Finnish partner have a weaker overlap between industrial niching and workplace segregation both compared to singles and migrants living with a migrant partner. Finally, the overlap between industrial niching and workplace segregation weakens with rising skills level.

\section{Discussion and Conclusions}

Two separate strands of research deal with industrial niching and workplace segregation. In this article, a first attempt was made to connect these two dimensions of immigrant labour market outcomes by jointly estimating the overlap between workplace segregation and industrial niching.

Based on a study of Estonian, Swedish and Russian migrants in Finland, and controlling for sociodemographic characteristics of migrants and measures of integration, we find a strong and positive overlap between workplace segregation and industrial niching. This implies that there are common forces that push migrants into employment in a particular industry and/or workplace. The main explanatory idea behind positive and strong interdependence between the level of workplace segregation and industrial niching relies on social networks that operate heavily in job search and hiring processes that link migrants to certain workplaces and industrial niches (Dustmann et al., 2016; Goel \& Lang, 2019; McGuinness \& Byrne, 2014).

In Finland, like in most European countries, immigration policy is strongly based on labour market needs. The sorting of migrant labour in certain industries and workplaces may be, first, due to the shortage of domestic labour in some sectors such as construction. Furthermore, the free labour market of the European Union makes it easier to attract workers from lowerincome member states. Hence, a high share of Estonian construction workers moves to Finland seeking higher wages (Anniste \& Tammaru, 2014). Second, niched and segregated workplaces may emerge because of the mushrooming of ethnic businesses in some sectors such as ethnic restaurants (Lee, 2019) or due to a hiring process that is based on co-ethnic networks and rely on co-ethnic residential pools. Both mechanisms tend to contribute to the niching of immigrants into certain industries as well as into certain workplace establishments (Strömgren et al., 2014). In other words, industrial niching in cities is inherently spatial; immigrant workers tend to concentrate not only into certain jobs and industries but also into certain workplaces located in certain residential areas within the city (Wright et al., 2010).

We find that the level of interdependence between workplace segregation and industrial niching varies for gender and skills level as well as across ethnic groups. In earlier studies (Joassart-Marcelli, 2014; McLafferty \& Preston, 2019), it was found that employment profiles for males and females are different. Following the previous explanations (Lindenlaub \& Prummer, 2016) that females and males use different resources in the job

Table 3. GSEM estimates by gender, family status and occupation.

\begin{tabular}{|c|c|c|c|c|c|c|c|c|}
\hline & \multicolumn{2}{|c|}{ Gender } & \multicolumn{3}{|c|}{ Family status } & \multicolumn{3}{|c|}{ Occupation } \\
\hline & Female & Male & Single & $\begin{array}{l}\text { Migrant } \\
\text { partner }\end{array}$ & $\begin{array}{l}\text { Finnish } \\
\text { partner }\end{array}$ & $\begin{array}{l}\text { Manual } \\
\text { worker }\end{array}$ & $\begin{array}{c}\text { Lower } \\
\text { white-collar }\end{array}$ & $\begin{array}{c}\text { Higher } \\
\text { white-collar }\end{array}$ \\
\hline Overlap (Rho) & $.84^{* * *}$ & $.67 * * *$ & $.78 * * *$ & $.78^{* * *}$ & $.62 * * *$ & $.83 * * *$ & $.66 * * *$ & $.48 * * *$ \\
\hline
\end{tabular}

Notes: *significant at $10 \%$; ${ }^{* *}$ significant at $5 \% ;{ }^{* *}$ significant at $1 \%$. Source: Authors' own calculations based on Finnish registry data set (years 2004-2013) not publicly available. 
searching process, in the context of the Helsinki labour market, we revealed that females tend to funnel in segregated and simultaneously niched positions more likely than males. Gender variation in overlapping could be explained by the occupational and, hence, skills level division (Peetz \& Murray, 2019; Wright \& Ellis, 2000). Females may take lower positions and not take higher work responsibilities on purpose as it allows them to spend more time outside jobs. However, our findings strongly depend on the context. As Wright and Ellis (2000) suggested, gender differences are not universal and should be interpreted in the framework of cross-cultural and interethnic background as well as skills level. Hence, we suspect that gender overlapping across the same skills level and from the same ethnic group will be smaller and men and women tend to work alongside each other.

As previous research shows, low-skilled migrants tend to be employed either in segregated workplaces (Glitz, 2014) or in niched industries (Liu, 2011). Our findings show that there is a stronger overlap between niching and segregation among the low-skilled migrants compared to high-skilled migrants. Across all skills groups, manual workers have the highest likelihood to be employed in a segregated workplace or niched industry. This result holds for all ethnic groups, i.e., it is not related to coming from a less affluent or more affluent country of origin, or from within the European Union with little formal restrictions on labour mobility or from a third country with much stricter recruitment rules.

However, variations between migrant countries of origin are more important. The degree of overlap is the highest for Estonian migrants, with little difference between Sweden and Russia. Estonia and Sweden are linguistically and culturally very similar countries to Finland. Immigrants originally from Estonia and Sweden benefit from the EU free labour market movement and have many opportunities of employment in Finland. Dissimilar to Estonia, the wealth level in Sweden is comparatively higher than in Finland. Our results revealed that the overlapping coefficient is significantly larger for Estonian immigrants than for Swedes. We hypothesise that this is due to the wealth gap between home and host countries: Coming from a less affluent country, immigrants are willing to take second jobs as they often compare wages in home and host countries.

The Russian language is more distant from Finnish compared to Estonian and Swedish, and the wealth level in Russia is lower than in Finland. In this context, one could expect the strongest overlap between niching and segregation for Russians due to cultural diversity (Ely \& Thomas, 2001). However, our findings are not in line with those expectations. This implies that explanations other than linguistic-cultural similarity and countries' wealth levels are needed to understand migrant sorting into industrial niches and workplace establishments, and immigration policy may be a crucial factor. The barrier for getting permission to enter Finland is high for Russian migrants, who must have a pre-signed work contract. This requirement aims to hire middle or highly-skilled workers, among which the overlap between industrial niching and workplace segregation is not so high. Hence, skills-selection produced by migration policy leads to lower levels of both industrial niching and segregation in the workplace establishments.

While skill-selection may be an important factor explaining a lower overlap between niching and segregation among Russian migrants, both cultural similarity and coming from a high-income context may explain the lower isolation of Swedes on the Finnish labour market compared to Estonians. In short, Swedes have a long and successful history of immigration to Finland that makes it easy to for Finnish employers to recognise their previous work experience and level of education and later hire them (Ansala et al., 2020). Since both Estonians and Swedes are linguistically close to Finns but experience very different outcomes in the Swedish labour market, coming from a wealthy country may also be related to different expectations and motivations. Swedish low-skilled workers are not motivated by the Finnish wage levels, unlike the low-skilled workers from Estonia. However, for high-skilled sectors, Swedish and Finnish wages could converge (Trading Economics, 2018), which makes sense for high-skilled Swedes to enter the Finnish labour market. Likewise, motives other than wage levels, such as career opportunities, may compensate the lower salary levels. Hence, the ethnic differences in the degree of overlap between workplace segregation and industrial niching stem from a complex relationship between linguistic and cultural factors, origin country context and immigration policy, with a high degree of cultural integration (Estonian migrants) not necessarily related to high levels of labour market integration.

These findings have strong policy implications. Notably, cultural differences may be of less importance than assumed. Rather, skill selection policies help to reduce migrant isolation in the labour market since the degree of overlap between industrial niching and workplaces segregation does not differ between Russian and Swedish migrants in Finland. Second, because of the overlap, labour market policies and employer hiring practices aiming at reducing one dimension of labour market inclusion (e.g., reducing workplace segregation) would also reduce the other dimension (industrial niching). However, since the overlap between industrial niching and workplace segregation is not perfect, policies and hiring practices aiming at both dimensions are most effective. Hence, a combined sector-employer-based policy may reduce the isolation of migrants in host country labour markets, as the case of Russian migrants in the Finnish labour market shows.

\section{Acknowledgments}

The research leading to these results received funding from the Estonian Research Council (Institutional 
Research grant number PUT PRG306), the European Research Council under the European Horizon 2020 framework (UPLIFT), the Strategic Research Council at the Academy of Finland, Decision no. 303665 (URMI project, "Urbanisation, Mobilities and Immigration") and the KONE Foundation (Suomen Silta 3.0). The authors thank their colleagues from the School of Economics (Tiiu Paas) and the Department of Human Geography (Anneli Kährik) for their valuable feedback and support through this research. We are also grateful to anonymous reviewers who improved our article.

\section{Conflict of Interests}

The authors declare no conflict of interests.

\section{Supplementary Material}

Supplementary material for this article is available online in the format provided by the author (unedited).

\section{References}

Alaverdyan, S., \& Zaharieva, A. (2019). Immigration, social networks and occupational mismatch (Working Paper No. 612). Bielefeld: Center for Mathematical Economics.

Anniste, K., \& Tammaru, T. (2014). Ethnic differences in integration levels and return migration intentions: $A$ study of Estonian migrants in Finland. Demographic Research, 30, 377-412.

Ansala, L., Åslund, O., \& Sarvimäki, M. (2020). Immigration history, entry jobs, and the labor market integration of immigrants (IZA Working Paper No. 13089). Bonn: Institute of Labor Economics.

Arrow, K. J. (1998). What has economics to say about racial discrimination? Journal of Economics Perspectives, 12(2), 91-100.

Åslund, O., \& Engdahl, M. (2019). Open borders, transport links, and local labor markets. International Migration Review, 53(3), 706-735.

Bayer, P., Ross, S. L., \& Topa, G. (2008). Place of work and place of residence: Informal hiring networks and labor market outcomes. Journal of Political Economy, 116(6), 1150-1196.

Bursell, M., \& Jansson, F. (2018). Diversity preferences among employees and ethnoracial workplace segregation. Social Science Research, 74, 62-76.

Bygren, M. (2013). Unpacking the causes of segregation across workplaces. Acta Sociologica, 56(1), 3-19.

Catanzarite, L., \& Aguilera, M. B. (2002). Working with co-ethnics: Earnings penalties for Latino immigrants at Latino jobsites. Social Problems, 49(1), 101-127.

Christopher, S. C., \& Leslie, T. F. (2015). Assessing immigrant niches across large American metropolitan areas. Population, Space and Place, 21(2), 171-192.
Doeringer, P. P., \& Piore, M. J. (1985). Internal labor markets and manpower analysis. Armonk, NY: M.E. Sharpe.

Dustmann, C., Fabbri, F., \& Preston, I. (2005). The impact of immigration on the British labour market. The Economic Journal, 115(507), 324-341.

Dustmann, C., Glitz, A., Schönberg, U., \& Brücker, H. (2016). Referral-based job search networks. The Review of Economic Studies, 83(2), 514-546.

Ellis, M., \& Almgren, G. (2009). Local contexts of immigrant and second-generation integration in the United States. Journal of Ethnic and Migration Studies, 35(7), 1059-1076.

Ellis, M., Wright, R., \& Parks, V. (2004). Work together, live apart? Geographies of racial and ethnic segregation at home and at work. Annals of the Association of American Geographers, 94(3), 620-637.

Ely, R. J., \& Thomas, D. A. (2001). Cultural diversity at work: The effects of diversity perspectives on work group processes and outcomes. Administrative Science Quarterly, 46(2), 229-273.

Fellini, I., Guetto, R., \& Reyneri, E. (2018). Poor returns to origin-country education for non-Western immigrants in Italy: An analysis of occupational status on arrival and mobility. Social Inclusion, 6(3), 34-47.

Findlay, A., \& Cranston, S. (2015). What's in a research agenda? An evaluation of research developments in the arena of skilled international migration. International Development Planning Review, 37(1), 17-31.

Gleave, S. (2017). Started from the bottom now we're where? African-American and Latino niching in Gulf Coast metros. Social Science Quarterly, 98(5), 1691-1710.

Glitz, A. (2014). Ethnic segregation in Germany. Labour Economics, 29, 28-40.

Goel, D., \& Lang, K. (2019). Social ties and the job search of recent immigrants. ILR Review, 72(2), 355-381.

González-Ferrer, A., Obućina, O., Cortina, C., \& CastroMartín, T. (2018). Mixed marriages between immigrants and natives in Spain: The gendered effect of marriage market constraints. Demographic Research, 39, 1-32.

Halbmeier, C. (2019). Wealth and savings of migrants and natives in Germany (German Institute for Economic Research Paper). Berlin: DIW Berlin. http:// dx.doi.org/10.2139/ssrn.3315528

Hall, M., Iceland, J., \& Yi, Y. (2019). Racial separation at home and work: Segregation in residential and workplace settings. Population Research and Policy Review, 38(5), 671-694.

Hanson, S., \& Pratt, G. (1992). Dynamic dependencies: A geographic investigation of local labor markets. Economic Geography, 68(4), 373-405.

Hayfron, J. E. (2001). Language training, language proficiency and earnings of immigrants in Norway. Applied Economics, 33(15), 1971-1979.

Hedberg, C., \& Tammaru, T. (2013). 'Neighbourhood effects' and 'city effects': The entry of newly arrived 
immigrants into the labour market. Urban Studies, 50(6), 1165-1182.

Hellerstein, J. K., Mclnerney, M., \& Neumark, D. (2011). Neighbors and coworkers: The importance of residential labor market networks. Journal of Labor Economics, 29(4), 659-695.

Hensvik, L., \& Skans, O. N. (2016). Social networks, employee selection and labor market outcomes. Journal of Labor Economics, 34(4), 825-867.

Hoffman, M. (2017). The value of hiring through employee referrals in developed countries. IZA World of Labor, 2017(369). Retrieved from https:// wol.iza.org/articles/the-value-of-hiring-throughemployee-referrals-in-developed-countries/long

Joassart-Marcelli, P. (2014). Gender, social network geographies, and low-wage employment among recent Mexican immigrants in Los Angeles. Urban Geography, 35(6), 822-851.

Joona, P. A., Gupta, N. D., \& Wadensjö, E. (2014). Overeducation among immigrants in Sweden: Incidence, wage effects and state dependence. IZA Journal of Migration, 3(1). https://doi.org/10.1186/2193-90393-9

Klein, T. (2001). Intermarriages between Germans and foreigners in Germany. Journal of Comparative Family Studies, 32(3), 325-346.

Lancee, B. (2016). Job search methods and immigrant earnings: A longitudinal analysis of the role of bridging social capital. Ethnicities, 16(3), 349-367.

Lee, C. T. (2019). Improvising 'nonexistent rights': Immigrants, ethnic restaurants, and corporeal citizenship in suburban California. Social Inclusion, 7(4), 79-89.

Light, A., \& Nandi, A. (2007). Identifying race and ethnicity in the 1979 national longitudinal survey of youth. Population Research and Policy Review, 26(2), 125-144.

Lindenlaub, I., \& Prummer, A. (2016). Gender, social networks and performance (CWPE No. 807). Cambridge: University of Cambridge.

Liu, C. Y. (2011). Employment concentration and job quality for low-skilled Latino immigrants. Journal of Urban Affairs, 33(2), 117-142.

Liu, C. Y., \& van Holm, E. J. (2019). The geography of occupational concentration among low-skilled immigrants. Economic Development Quarterly, 33(2), 107-120.

Longhi, S. (2019). Does geographical location matter for ethnic wage gaps? Journal of Regional Science, 60(3), 538-557.

Manning, A., \& Petrongolo, B. (2017). How local are labor markets? Evidence from a spatial job search model. American Economic Review, 107(10), 2877-2907.

McGuinness, S., \& Byrne, D. (2014). Examining the relationships between labour market mismatches, earnings and job satisfaction among immigrant graduates in Europe (IZA Working Paper No. 8440). Bonn: Institute of Labor Economics.

McLafferty, S., \& Preston, V. (2019). Who has long com- mutes to low-wage jobs? Gender, race, and access to work in the New York region. Urban Geography, 40(9), 1270-1290.

Napierała, J., \& Wojtyńska, A. (2017). Trapped in migrants' sectors? Polish women in the Icelandic labour market. International Migration, 55(1), 128-141.

Peach, C. (2005). The ghetto and the ethnic enclave. In D. P. Varady (Ed.), Desegregating the city (pp. 31-48). Albany, NY: Sunny Press.

Peetz, D., \& Murray, G. (2019). Women's employment, segregation and skills in the future of work. Labour \& Industry: A Journal of the Social and Economic Relations of Work, 29(1), 132-148.

Penninx, R. (2005). Integration of migrants: Economic, social, cultural and political dimensions. The New Demographic Regime: Population Challenges and Policy Responses, 5, 137-152.

Rahnu, L., Puur, A., Kleinepier, T., \& Tammaru, T. (2019). The role of neighbourhood and workplace ethnic contexts in the formation of inter-ethnic partnerships: A native majority perspective. European Journal of Population, 36, 247-276.

Ruiz, I., \& Vargas-Silva, C. (2018). Differences in labour market outcomes between natives, refugees and other migrants in the UK. Journal of Economic Geography, 18(4), 855-885.

Sánchez-Domínguez, M., \& Fahlén, S. (2018). Changing sector? Social mobility among female migrants in care and cleaning sector in Spain and Sweden. Migration Studies, 6(3), 367-399.

Sassen, S. (1990). Economic restructuring and the American city. Annual Review of Sociology, 16(1), 465-490.

Sassen, S. (2011). The global street: Making the political. Globalizations, 8(5), 573-579.

Skaptadóttir, U. D. (2019). Transnational practices and migrant capital: The case of Filipino women in Iceland. Social Inclusion, 7(4), 211-220.

Söhn, J. (2013). Unequal welcome and unequal life chances: How the state shapes integration opportunities of immigrants. European Journal of Sociology/Archives Européennes de Sociologie, 54(2), 295-326.

Strömgren, M., Tammaru, T., Danzer, A. M., van Ham, M., Marcińczak, S., Stjernström, O., \& Lindgren, U. (2014). Factors shaping workplace segregation between natives and immigrants. Demography, 51(2), 645-671.

Tammaru, T., Strömgren, M., van Ham, M., \& Danzer, A. M. (2016). Relations between residential and workplace segregation among newly arrived immigrant men and women. Cities, 59, 131-138.

Tammaru, T., van Ham, M., Marcińczak, S., \& Musterd, S. (Eds.). (2015). Socio-economic segregation in European capital cities: East meets West (1st ed.). London: Routledge.

Telve, K. (2019). Family involved or left behind in migration? A family-centered perspective towards Estonia- 
Finland cross-border commuting. Mobilities, 14(5), 715-729.

Tesfai, R. (2019). Does country context matter? Sub-Saharan and North African immigrants' labour market outcomes in France and Spain. International Migration, 57(1), 298-317.

Tomaskovic-Devey, D., Hällsten, M., \& Avent-Holt, D. (2015). Where do immigrants fare worse? Modeling workplace wage gap variation with longitudinal employer-employee data. American Journal of Sociology, 120(4), 1095-1143.

Trading Economics. (2018). Finland high-skilled wages. Trading Economics. Retrieved from https:// tradingeconomics.com/finland/wages-high-skilled

Tuccio, M. (2020). Skills proficiency and the labour market outcomes of migrants (Working Paper No. 12). Paris: OECD Publishing.
Visintin, S., Tijdens, K., \& van Klaveren, M. (2015). Skill mismatch among migrant workers: Evidence from a large multi-country dataset. IZA Journal of Migration, 4(1). https://doi.org/10.1186/s40176-015-0040-0

Waldinger, R. (1994). The making of an immigrant niche. International Migration Review, 28(1), 3-30.

Wang, Q., \& Pandit, K. (2007). Measuring ethnic labour market concentration and segmentation. Journal of Ethnic and Migration Studies, 33(8), 1227-1252.

Wright, R., \& Ellis, M. (2000). The ethnic and gender division of labor compared among immigrants to Los Angeles. International Journal of Urban and Regional Research, 24(3), 583-600.

Wright, R., Ellis, M., \& Parks, V. (2010). Immigrant niches and the intrametropolitan spatial division of labour. Journal of Ethnic and Migration Studies, 36(7), 1033-1059.

\section{About the Authors}

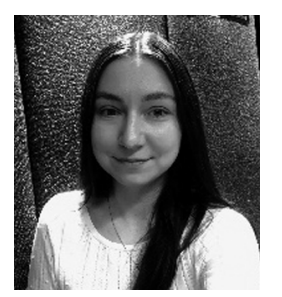

Anastasia Sinitsyna is a 4th year PhD student and Junior Research Fellow in the School of Economics and Business Administration at the University of Tartu, Estonia. She studies ethnic segregation and its effects on labour markets and economic and social integration of immigrants. Her additional research interests rely on topics of new labour market forms and spaces.

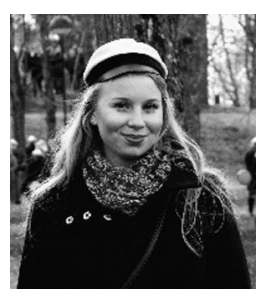

Karin Torpan is a Doctoral student in Human Geography at the University of Tartu, Estonia, and the University of Turku, Finland. Her research focus is on housing and neighbourhood changes, ethnic and socio-economic segregation and studies of return migration intentions. In the frame of her doctoral studies, her research focuses are mainly on the context of the Nordic countries.

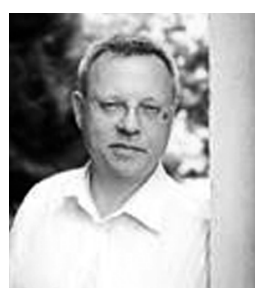

Raul Eamets is a Professor of Macroeconomics in the School of Economics and Business Administration at the University of Tartu, Estonia. He is also Dean of the Faculty of Social Science. His research interests are based on topics of labour market effects of migration and policy implications for integration.

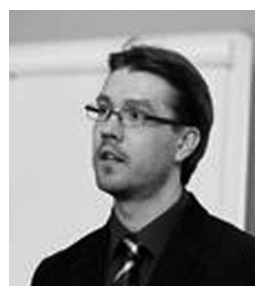

Tiit Tammaru is a Professor of Urban and Population Geography at the University of Tartu, Estonia, and also a Member of Estonian Academy of Sciences. His research interests include segregation in different life domains, residential mobility and housing career paths as well as social and economic inequalities in different contexts. 